\section{REFERENCES}

Committee on Medical Aspects of Radiation in the Environment (1996) The incidence of cancer and leukaemia in young people in the vicinity of the Sellafield site, West Cumbria: further studies and an update of the situation since the publication of the report of the Black Advisory Group in 1984 COMARE 4th Report, London: HMSO

Feychting M, Svensson D, Ahlbom A (1988) Exposure to motor vehicle exhaust and childhood cancer. Scand J Work Environ Health 24: 8-11

Greaves M (2002) Clinical Review: Science, medicine and the future - Childhood leukaemia. $\mathrm{Br}$ Med J 324: 283 - 287

Harrison RM, Leung PL, Sommervaille L, Smith R, Gilman E (1999) Analysis of incidence of childhood cancer in the West Midlands of the United Kingdom in relation to proximity to main roads and petrol stations. Occup Environ Med 56: $774-780$

Henshaw DL, Allen JE, Keitch PA, Randle PH (1994) The spatial distribution of naturally occurring ${ }^{210} \mathrm{Po}$ and ${ }^{226} \mathrm{Ra}$ in children's teeth. Int J Radiat Biol 66: $815-826$

Henshaw DL, Keitch PA, James PR (1995) Lead-210, polonium-210 and vehicle exhaust pollution. Lancet 245: $324-325$

Kaletsch U, Kaatsch P, Meinert R, Schüz J, Czarwinski R, Michaelis J (1999) Childhood cancer and residential radon exposure - results of a population-based case-control study in Lower Saxony (Germany). Radiat Environ Biophys 38: $211-215$

Knox EG, Gilman EA (1997) Hazard proximities of childhood cancers in Great Britain from 1953-80. J Epidemiol Community Health 51: 151-159

Kohli S, Brage HN, Löfman O (2000) Childhood leukaemia in areas with different radon levels: a spatial and temporal analysis using GIS. J. Epidemiol. Community Health 54: $822-826$
Lubin JH, Linet MS, Boice Jr JD, Buckley J, Conrath SM, Hatch EE, Kleinerman RA, Tarone RE, Wacholder S, Robison LL (1998) Case-control study of childhood acute lymphoblastic leukaemia and residential radon exposure. J Nat Cancer Inst 90: 294-300

Pearson RL, Wachtel H, Ebi KL (2000) Distance-weighted traffic density in proximity to a home is a risk factor for leukaemia and other childhood cancers. J Air Waste Manag Assoc 50: 175-180

Savitz DA, Chen J (1990) Parental occupation and childhood cancer: review of epidemiologic studies. Environ Health Perspectives 88: 325-337

Savitz DA, Feingold L (1989) Association of childhood cancer with residential traffic density. Scand J Work Environ Health 15: 360-363

Shu XO, Stewart P, Wen W, Han D, Potter JD, Buckley JD, Heineman E, Robison LL (1999) Parental occupational exposure to hydrocarbons and risk of acute lymphocytic leukaemia in offspring. Cancer Epidemiol Biomarkers Prev 8: $783-791$

Simmonds JR, Robinson CA, Phipps AW, Muirhead CR, Fry FA (1995) Risks of Leukaemia and other cancers in Seascale from all sources of ionising radiation exposure. Didcot: HMSO

Stjernfeldt M, Samuelsson L, Ludvigsson J (1987) Radiation in dwellings and cancer in children. Paediatr Haematol Oncol 4: 55-61

Steinbuch M, Weinberg CR, Buckley JD, Robison LL, Sadler DP (1999) Indoor residential radon exposure and risk of childhood acute myeloid leukaemia. Br J Cancer 81: $900-906$

UKCCS Investigators (2002) The United Kingdom Childhood Cancer Study of exposure to domestic sources of ionising radiation: 1: radon gas. $\mathrm{Br} J$ Cancer 86: $1721-1726$

\title{
The role of aspirin in carcinogenesis
}

\section{GJ Caine ${ }^{*, 1,2}$, ST Kehoe ${ }^{2}$ and GYH Lip'}

'University Department of Medicine, City Hospital, Birmingham B/8 7QH, UK; ${ }^{2}$ Department of Gynaecological Oncology, Birmingham Women's Hospital, Birmingham B/5 2TG, UK

British Journal of Cancer (2002) 87, 1337 - | 338. doi:I0.1038/sj.bjc.6600670 www.bjcancer.com

(c) 2002 Cancer Research UK

Sir

We read with interest the excellent paper by Akhmedkhanov et al (2002) regarding aspirin use and the incidence of lung cancer. We would like to offer another possible anti-cancer property of aspirin, namely, the inhibition of phenolsulphotransferase (PST) activity.

PSTs are found throughout the body, but the bowel, liver and platelets are known to contain particularly high activities of this enzyme. PSTs are cytosolic and exist in two forms: (i) P-PST, which selectively sulphates micromolar concentrations of phenols; and (ii) M-PST, which is similarly selective for aromatic amines.

The main function of this sulphation is to scavenge low concentrations of endogenous and exogenous toxins from the body, but

*Correspondence: GJ Caine; University Department of Medicine, City Hospital, Birmingham BI8 7QH, UK; E-mail: grahamcaine@hotmail.com the lability of the phenolic sulphate-ester bond means it is liable to cause the formation of electrophilic free radicals. These react chemically with DNA which may cause mutations leading to neoplasia (Coughtrie, 1996).

Food cooking can result in a wide variety of mutagenic compounds, including polyaromatic hydrocarbons and heterocyclic amines, especially if the food becomes charred when grilled or barbequed. Certainly, several polyaromatic hydrocarbons have been shown to be activated by hydroxylation to phenols followed by sulphation via P-PST to the final mutagenic form (Grover, 1986). P-PST has also been found to be responsible for the activation of heterocyclic amines by $\mathrm{N}$-sulphation, for example, the bladder carcinogen 2-napthylamine (Hernandez et al, 1991) and a wide variety of carcinogenic Nhydroxy arylamines (Chou et al, 1995).

Thus, inhibition of P-PST would block one route of activation for both main groups of carcinogen found in food. Indeed, Rao 
and Duffel (1991) have shown that salicylic acid, the initial breakdown product of aspirin, is a potent inhibitor of aryl sulphotransferase IV (AST IV), at least in the rat - and AST IV is the rat equivalent of human PST enzymes. Other studies (Boberg et al, 1983; Tsutumi et al, 1995) have also shown that sulphotransferase inhibitors dramatically reduces the potency of sulphation activated carcinogens in both mice and hamsters.

\section{REFERENCES}

Akhmedkhanov A, Toniolo P, Zeleniuch-Jacquotte A, Koenig KL, Shore RE (2002) Aspirin and lung cancer in women. Br J Cancer 87: 49-53

Boberg EW, Miller EC, Miller JA, Poland A, Liem A (1983) Strong evidence from studies with brachymorphic mice and pentachlorophenol: that $1^{\prime}$ sulfooxysafrole is the major ultimate electrophilic and carcinogenic metabolite of 1'-hydroxysafrole in mouse liver. Cancer Res 43: 5163-5173

Chou H-C, Lang NP, Kadlubar FF (1995) Metabolic activation of N-hydroxy arylamines and N-hydroxy heterocyclic amines by human sulphotransferase(s). Cancer Res 55: 525-529

Coughtrie MWH (1996) Sulphation catalysed by the human cytosolic sulphotransferases - chemical defence or molecular terrorism? Hum Expl Toxicol 15: $547-555$
We would therefore suggest that the action of salicylic acid on P-PST, by preventing the excessive activation of carcinogens, may represent another possible pathway by which aspirin may reduce cancer risk.
Grover PL (1986) Pathways involved in the metabolism and activation of polycyclic hydrocarbons. Xenobiotica 16: $915-931$

Hernandez JS, Powers SP, Weinshilboum RM (1991) Human liver arylamine n-sulfotransferase activity. Thermostable phenol sulfotransferase catalyzes the N-sulfation of 2-napthylamine. Drug Metab Dispos 19: 1071-1079

Rao SI, Duffel MW (1991) Inhibition of aryl sulfotransferase by carboxylic acids. Drug Metab Dispos 19: 453-455

Tsutumi M, Noguchi O, Okita S (1995) Inhibitory effects of sulfation inhibitors on initiation of pancreatic ductal carcinogenesis by N-nitrosobis (2oxopropyl) amine in hamsters. Carcinogenesis 16: 457-459 